\title{
BMJ Global Health Ethics-driven policy framework for implementation of movement restrictions in pandemics
}

\author{
Siddhesh Zadey (D) , ,2 Surabhi Dharmadhikari (D) ,1,3 \\ Pradeeksha Mukuntharaj (D) ${ }^{1,4}$
}

\begin{abstract}
To cite: Zadey S,
Dharmadhikari S, Mukuntharaj P. Ethics-driven policy framework for implementation of movement restrictions in pandemics. BMJ Global Health 2021;6:e005202. doi:10.1136/ bmjgh-2021-005202
\end{abstract}

Handling editor Seye Abimbola SD and PM contributed equally.

Received 30 January 2021 Accepted 13 May 2021

\section{Check for updates}

(C) Author(s) (or their employer(s)) 2021. Re-use permitted under CC BY-NC. No commercial re-use. See rights and permissions. Published by BMJ.

${ }^{1}$ Association for Socially Applicable Research, Pune, India 2Duke Global Health Institute, Duke University, Durham, North Carolina, USA

${ }^{3}$ Rajashree Chatrapati Shahu Maharaj Government Medical College, Kolhapur, Maharashtra, India

${ }^{4}$ Urban Health and Training Centre India, Mumbai, India

Correspondence to Mr Siddhesh Zadey; sidzadey@asarforindia.org

\section{ABSTRACT}

In the ongoing COVID-19 pandemic, countries across the globe undertook several stringent movement restrictions to prevent the virus spread. In April 2020, around 3.9 billion people in 90 countries were contained in their homes. Discourse on the ethical questions raised by such restrictions while historically rich is absent when it comes to pragmatic policy considerations by the decisionmakers. Drawing from the existing literature, we present a unified ethical principles-pragmatic considerations-policy indicators framework flexibly applicable across different countries and contexts to assess the ethical soundness of movement-restricting policies. Our framework consolidates 11 unique but related ethical principles (harm, justifiability, proportionality, least restrictive means, utility efficiency, reciprocity, transparency, relevance, equity, accountability, and cost and feasibility). We mapped each ethical principle to answerable questions or pragmatic considerations to subsequently generate 34 policy indicators. These policy indicators can help policymakers and health practitioners to decide the ethically substantiated initiation of movement restrictions, monitor progress and systematically evaluate the imposed restrictions. As an example, we applied the framework to evaluate the first two phases of the largest lockdown (March-May 2020) implemented nationwide in India for its adherence to ethical principles. The policy indicators revealed ethical lapses in proportionality, utility efficiency and accountability for India's lockdown that should be focused on in subsequent restrictions. The framework possesses value towards ensuring that movement-restrictive public health interventions across different parts of the world in the ongoing pandemic and possible future outbreaks are ethically sound.

\section{INTRODUCTION}

Globally, COVID-19 has resulted in over 3294009 deaths and 158366256 cases as of 10 May 2021. ${ }^{1}$ To limit the loss of life at the hands of an unknown virus, governments across the world introduced movement restrictions of varying stringency as public health interventions. ${ }^{2}$ The large-scale mass movement restrictions with stay-at-home regulations referred to as 'lockdowns' ${ }^{3}$ hereafter, arguably, have been the most restrictive non-pharmaceutical
Summary box

In recent years, autonomy and liberty-restrictive public health interventions have generated ethical debates and necessitated guidelines, and the COVID-19 movement restrictions such as lockdowns reinvigorated this ethical dilemma.

- An applied ethics framework for policymakers to make quick evaluations of the ethical soundness of movement-restrictive policy decisions is urgentIy needed in view of the COVID-19 pandemic to be better prepared for future pandemics but is missing.

- We present a novel integrated ethical principlespragmatic considerations-measurable policy indicators framework based on an amalgamation of unique ethical principles drawn from a rigorous review of the existing literature on the ethics of movement restrictions with each ethical principle mapped to answerable questions or pragmatic considerations to subsequently generate 34 policy indicators.

- We also depict ethical lapses in proportionality, utility efficiency and accountability for the largest such restriction in the COVID-19 pandemic, that is, India's lockdown.

- Our framework bridges the gap between public health ethics and policymaking in the context of movement restrictions through an easy-to-use tool that can be applied across countries to assess the ethical implications of policies in the face of ongoing and future pandemics.

public health intervention against the ongoing pandemic. The WHO had described the first lockdown implemented in Wuhan, China on 23 January 2020 as 'unprecedented in public health history'. Since Wuhan, lockdowns have been implemented in over 70 countries, the largest one being in India. In the first week of April 2020, about 3.9 billion people worldwide were contained in lockdowns in their respective countries. ${ }^{5}$ The crosscountry evaluations using disparate analytical methods have converged on movement restrictions being effective, advocating for the benefits of early-on implementation. ${ }^{367}$ Even 
so, all restrictions, particularly lockdowns, have led to significant economic losses and humanitarian suffering. One-third of all workers around the world lived in a place with severe workplace closure leading to a loss of over 400 million full-time jobs in the second quarter of $2020 .^{8}$ During the national and local lockdowns, about 1.5 billion children were put out of schools. ${ }^{9}$ Conservatively, the stalling of economies was predicted to push 71 million people into extreme poverty. ${ }^{10}$ In India, the debilitations of the lockdown led to over 300 deaths. ${ }^{11}$ Researchers, policymakers, and politicians have focused largely on the efficacy of movement restrictions and hailed their importance particularly noting the hypothetical counterfactual harms. ${ }^{12-14}$ However, studies looking at the ethics of such restrictions are negligible. For instance, updated COVID-19 guidelines by the WHO or other global stakeholders for ethically appropriate implementation of movement restrictions such as lockdown seem to be missing. In several instances, the liberty, autonomy, and livelihood of people have been disproportionately restricted without any transparent communication or reciprocal benefits from the authorities implementing the movement restrictions. ${ }^{15}$ We assume that incorporating ethical considerations can enhance the effectiveness of such movement restrictions by generating the necessary conditions for compliance and public participation. Drawing from existing literature, we present a unified principles-considerations-indicators framework that could be used by decision-makers for value-based implementation, monitoring and evaluation of movement restrictions.

During the COVID-19 pandemic, the most stringent form of movement restriction was the lockdown. Therefore, for an exemplary application of the framework, we decided to focus on the ethics of the lockdown. One of the largest, longest and most stringent lockdowns was implemented in India from 25 March to 3 May 2020 that drew global attention. ${ }^{16}{ }^{17}$ Also, we believe that the framework should be applied by stakeholders that understand the region's sociopolitical context. Given our familiarity with the Indian context and widespread global attention to its lockdown, we demonstrate an exemplary application of the framework for the evaluation of the nationwide lockdown in India that could help researchers and policymakers to understand the ethical soundness of the past response. While inexhaustive, the framework is meant to initiate a discussion around and provide an objective structure for understanding the ethics of movement restrictions as we face waves of outbreaks in the ongoing pandemic and for future pandemics.

\section{ETHICS PRINCIPLES IN THE FRAMEWORK}

The ethics of voluntary and imposed movement restrictions have been previously discussed for infectious disease outbreaks and other biohazards. In 2001, Barbera and colleagues ${ }^{18}$ examined the ethical considerations for large-scale quarantine for bioterrorism threats. They primarily focused on assessing the need, feasibility and cost-benefit ratio. Arguably, these ethical considerations for large-scale quarantines ${ }^{18}$ could be adapted for lockdowns in the ongoing COVID-19 pandemic. In the context of the 2003 severe acute respiratory syndrome epidemic, Upshur discussed ethical principles of harm, proportionality, reciprocity and transparency (see table 1) as requisite justifications for public health interventions, ${ }^{19}$ and applied them to the imposed and voluntary quarantines. ${ }^{20}$ In 2007, the WHO's report on the influenza pandemic discussed the ethical principles to be upheld by governments in case of movement restrictions. ${ }^{21}$ Beyond those suggested by Upshur, this report also brought forward social justice, liberty, confidentiality, fair process, efficiency and accountability as requirements for ethical imposition of restrictions. In 2015, the Presidential Commission for the Study of Bioethical Issues listed out ethical considerations for restrictive measures in response to the public health planning for the Ebola epidemic. ${ }^{22}$ The commission report recognised that an ethical implementation should adhere to considerations of the harm, reciprocity, least infringement, evidencebased action proportionality (as beneficence and nonmaleficence), justice and fairness, and ensuring equitable benefits sharing across socioeconomic strata. In 2016, the WHO released generic guidance for ethical management of infectious disease outbreaks. ${ }^{23}$ Recommendations for restrictions on freedom of movement included the justifiable basis for imposing restrictions (known harm and evidence-based action), least restrictive means, cost consideration (utility efficiency), ensuring humane conditions (reciprocal benefits), addressing financial and social consequences, due process protections (fair process), equitable application (fairness and distributive justice), and communication and transparency.

There is a conceptual convergence among these differently named sets of principles and considerations that are unified into an extended list of unique principles (table 1). It is noteworthy that this extended list demonstrates that some of the past discussions have ascribed different notions to a given principle or invoked different principles to present the same idea. For instance, there is a conceptual overlap between the basis of the necessity of intervention and its justifiability. Or that reciprocity has been used to represent the treatment of people at the hands of the authorities and also to denote the obligation of members of a community towards one another. There are also perceivable relationships among the principles. For instance, the harm principle can be considered a precondition for justifiability as without establishing the harm, imposing a restriction cannot be justified. In other words, the evidence underlying to denote harm also acts to affirm the justifiability of the interventions. In another instance, the least restrictive means principle can be thought of as a complement of the proportionality principle where the former concerns the stringency of the restrictions relative to each other, while the latter can be thought to address if the evolution 
Table 1 Framework for ethical principles, considerations, and policy indicators for implementing, monitoring, and evaluating lockdowns and other movement-restrictive non-pharmaceutical public health interventions

\begin{tabular}{|c|c|c|c|}
\hline Ethical principle & $\begin{array}{l}\text { Description of principle as per the } \\
\text { source reference }\end{array}$ & $\begin{array}{l}\text { Questions/considerations } \\
\text { raised under the principle }\end{array}$ & $\begin{array}{l}\text { Corresponding policy } \\
\text { monitoring and evaluation } \\
\text { indicators }\end{array}$ \\
\hline Harm/necessity & $\begin{array}{l}\text { Warranted by previous medical and } \\
\text { public health analyses }{ }^{18} \\
\text { Knowledge of measurable harm } \\
\text { Kresence of justifiable basis for } \\
\text { Parm } \\
\text { he } 23\end{array}$ & $\begin{array}{l}\text { Is there measurable } \\
\text { harm due to the disease } \\
\text { outbreak? }\end{array}$ & $\begin{array}{l}\text { Presence of scientific } \\
\text { evidence indicating harm } \\
\text { (eg, human to human } \\
\text { transmission, mortality) } \\
\text { Presence of decided metric } \\
\text { for harm measurement (eg, } \\
\text { death count, case count, } \\
\text { case fatality ratio) }\end{array}$ \\
\hline Justifiability & $\begin{array}{l}\text { Reasonable expectation that it } \\
\text { will have a significant impact; } \\
\text { reliance on best available scientific } \\
\text { evidence }{ }^{21} \\
\text { A justifiable basis for imposing } \\
\text { restrictions, based on evidence, with } \\
\text { continuous re-evaluation } \\
\text { Scientific justification for the } \\
\text { quarantine, plausible way } \\
\text { to determine who should be } \\
\text { quarantined } \\
\text { qu } \\
\text { Measures should be grounded in the } \\
\text { best available scientific evidence }\end{array}$ & $\begin{array}{l}\text { Is there scientific evidence } \\
\text { for the effectiveness of } \\
\text { the restriction to prevent/ } \\
\text { reduce harm? } \\
\text { Is the appropriateness } \\
\text { of the restriction being } \\
\text { continuously re-evaluated } \\
\text { as and when more } \\
\text { evidence emerges and } \\
\text { when the course of } \\
\text { the outbreak changes } \\
\text { (increase/decrease in } \\
\text { cases)? } \\
\text { Is the restriction being } \\
\text { withdrawn when new } \\
\text { evidence suggests that } \\
\text { the original rationale is no } \\
\text { longer applicable? } \\
\text { Are the restrictions placed } \\
\text { based on some valid } \\
\text { parameters (eg, case } \\
\text { counts in a locality) that } \\
\text { can determine who is at the } \\
\text { risk of harm? }\end{array}$ & $\begin{array}{l}\text { Presence of prior peer- } \\
\text { reviewed scientific } \\
\text { publications on the } \\
\text { effectiveness of restrictions } \\
\text { Successful historical } \\
\text { precedent (any instance } \\
\text { before) } \\
\text { Presence of a dedicated } \\
\text { response team for review } \\
\text { of literature, adequate } \\
\text { data collection, impact } \\
\text { evaluation and situational } \\
\text { monitoring to continuously } \\
\text { determine the effectiveness } \\
\text { of the restrictions }\end{array}$ \\
\hline $\begin{array}{l}\text { Least restrictive } \\
\text { means }\end{array}$ & $\begin{array}{l}\text { Mandatory measures should only be } \\
\text { instituted as a last resort }{ }^{21} 23 \\
\text { Voluntary measures should come } \\
\text { before mandatory ones }{ }^{20} \\
\text { Mentioned as the principle of least } \\
\text { infringement, which suggests } \\
\text { minimisation of impingement on } \\
\text { individual liberties }\end{array}$ & $\begin{array}{l}\text { Is the least restrictive } \\
\text { measure applied before } \\
\text { other measures severely } \\
\text { curbing individual and } \\
\text { communal rights? } \\
\text { Are voluntary restrictions } \\
\text { implemented before } \\
\text { mandatory restrictions? }\end{array}$ & $\begin{array}{l}\text { The number of steps } \\
\text { between the least (eg, } \\
\text { voluntary physical } \\
\text { distancing at public places) } \\
\text { and the most restrictive } \\
\text { (eg, mandatory lockdown) } \\
\text { measures } \\
\text { Whether sufficient time } \\
\text { intervals are given for every } \\
\text { set restrictive step to show } \\
\text { maximum effect* }\end{array}$ \\
\hline
\end{tabular}


Table 1 Continued

\begin{tabular}{|c|c|}
\hline Ethical principle & $\begin{array}{l}\text { Description of principle as per the } \\
\text { source reference }\end{array}$ \\
\hline Utility efficiency & $\begin{array}{l}\text { Potential benefits should outweigh } \\
\text { the adverse effects } \\
\text { 18 } \\
\text { Maximising aggregate benefits } \\
\text { under fewest costs }{ }^{21}\end{array}$ \\
\hline Reciprocity & $\begin{array}{l}\text { Provide means of mitigating adverse } \\
\text { effects; provide employment } \\
\text { protection; address financial and } \\
\text { employment consequences }{ }^{21} \\
\text { Ensuring humane conditions, } \\
\text { addressing financial and social } \\
\text { consequences }^{23} \\
\text { Communication strategies should } \\
\text { be designed to avoid stigmatisation } \\
\text { (mentioned under communication }^{\text {and transparency) }} \\
\text { - Society has a reciprocal obligation } \\
\text { to individuals for curtailing their } \\
\text { liberties } \\
\text { - The needs of detainees must be } \\
\text { addressed } \\
\text { - Those who bear the burden of } \\
\text { restrictive policies should be } \\
\text { supported by society and public }_{\text {agencies }}^{22}\end{array}$ \\
\hline
\end{tabular}

Questions/considerations raised under the principle

- Do the probable benefits of the restriction outweigh the probable risks?

- Are the restriction benefits achieved under the smallest costs?
Corresponding policy monitoring and evaluation indicators
Does the analysis of trade-off (eg, cost-benefit analysis) between loss of livelihood and other losses against deaths averted and cases averted show net positive benefit?* $\dagger$

Is the government reimbursing the individuals for curtailing their rights and for the loss of income/ loss of livelihood due to restrictions?

- Is the government placing relief mechanisms ensuring that the restricted individuals are not facing an undue burden?

- Are measures being taken to avoid stigmatisation and discrimination of those under restrictions?

- Are the societal groups less affected by the restriction taking care of those affected gravely by them?

- Cost and population coverage

- Presence of tax and loan payment concessions

- Postponing non-essential routine activities (eg, examinations, sports events, etc)

- Anti-discriminatory mass media practices

- Guidelines in place for responsible news media reporting to avoid discrimination and reduce stigma

- Presence of helplines to deal with mental health issues that may arise

- Surveys for awareness among people about avoiding discrimination

- Presence of grassroots ventures that help the impoverished groups

$\begin{array}{ll}\text { Transparency } & \text { Process and rationale of decision- } \\ & \text { making should be made transparent } \\ & \text { and public (mentioned as publicity of } \\ & \text { measures) } \\ & \text { Decision-makers should publicly } \\ & \text { explain the basis for decisions, } \\ & \text { including the uncertainties in } \\ & \text { decision-making } \\ & \text { Communicate clearly the justification } \\ & \text { for quarantine }{ }^{20}\end{array}$

Are the policy decisions regarding restrictions and their rationale being continuously informed to the public in comprehensible ways?
- Presence of press conferences in local languages

- Frequency of press conferences

- Presence of outreach methods and materials that are easy to understand, in local languages, and are widely distributed

- Presence of a public record of justification for the quarantine that is conveyed to lay people in local languages

Relevance $\quad$ Reasons, principles and evidence for the decision should be considered relevant by the affected stakeholders; develop strategies with community input ${ }^{21}$

- Solicit community members' views on restrictions (mentioned under communication and transparency) $)^{23}$
- Are the restrictions being implemented with feedback from the community that is affected by them? 
Table 1 Continued

\begin{tabular}{|c|c|c|c|}
\hline Ethical principle & $\begin{array}{l}\text { Description of principle as per the } \\
\text { source reference }\end{array}$ & $\begin{array}{l}\text { Questions/considerations } \\
\text { raised under the principle }\end{array}$ & $\begin{array}{l}\text { Corresponding policy } \\
\text { monitoring and evaluation } \\
\text { indicators }\end{array}$ \\
\hline Equity & $\begin{array}{l}\text { Special attention to protecting } \\
\text { vulnerable populations }{ }^{21} \\
\text { Equitable application of movement } \\
\text { restrictions }{ }^{23} \\
\text { Rights and liberties of restricted } \\
\text { individuals should be protected, } \\
\text { disproportionate distribution of } \\
\text { the benefits and burdens of PHI to } \\
\text { certain individuals/groups should be } \\
\text { prevented; mentioned as the justice } \\
\text { and fairness principle }\end{array}$ & $\begin{array}{l}\text { Is there equitable } \\
\text { distribution of the available } \\
\text { resources for relief to the } \\
\text { marginalised communities? } \\
\text { Is there a disproportionate } \\
\text { burden of the restriction on } \\
\text { vulnerable populations? }\end{array}$ & $\begin{array}{l}\text { Presence of food and } \\
\text { shelter security for the } \\
\text { below poverty line and low- } \\
\text { earning unorganised labour } \\
\text { groups affected by the } \\
\text { restrictions } \\
\text { Presence of domestic } \\
\text { violence helplines for } \\
\text { women and children } \\
\text { Availability of healthcare } \\
\text { access for the chronically ill } \\
\text { and elderly groups }\end{array}$ \\
\hline Accountability & $\begin{array}{l}\text { Provide individuals with legal } \\
\text { recourse to challenge their isolation/ } \\
\text { quarantine; revisability; appeal } \\
\text { mechanisms } \\
\text { Due process protections; decision- } \\
\text { makers should be held accountable } \\
\text { for abuse of authority } \\
\text { Allow for a process of appeal }\end{array}$ & $\begin{array}{l}\text { Are there measures in place } \\
\text { for individuals to express } \\
\text { grievances and challenge } \\
\text { the restrictions? } \\
\text { Can the decision-makers } \\
\text { be held accountable in } \\
\text { case of losses (economic/ } \\
\text { health)? }\end{array}$ & $\begin{array}{l}\text { Presence of grievance } \\
\text { redressal and feedback } \\
\text { portals } \\
\text { Presence of public } \\
\text { platforms to challenge the } \\
\text { restrictions by speaking to } \\
\text { authority figures } \\
\text { Presence of laws that allow } \\
\text { for a process of appeal } \\
\text { Uninterrupted and } \\
\text { autonomous working of } \\
\text { the judicial system for } \\
\text { fast-tracking the restriction- } \\
\text { related appeals } \\
\text { Mechanisms for demanding } \\
\text { reparations in case of life } \\
\text { and livelihood losses due to } \\
\text { restriction }\end{array}$ \\
\hline Cost and feasibility & $\begin{array}{l}\text { Countries should review if their } \\
\text { existing laws provide authority for } \\
\text { actions that may be needed in a } \\
\text { pandemic; mechanism in place for } \\
\text { enforcement/regulation }{ }^{21} \\
\text { Feasibility of implementation and } \\
\text { maintenance of quarantine } \\
\text { Costs and practical constraints need } \\
\text { to be taken into account }\end{array}$ & $\begin{array}{l}\text { Are financial and other } \\
\text { resources available to carry } \\
\text { out a restriction? } \\
\text { Does the country have legal } \\
\text { and disciplinary systems } \\
\text { in place to enforce the } \\
\text { restriction? } \\
\text { Are there enough resources } \\
\text { to provide food, shelter, } \\
\text { counselling to the } \\
\text { community during the } \\
\text { period of restriction? }\end{array}$ & $\begin{array}{l}\text { Presence of laws that allow } \\
\text { the implementation of } \\
\text { restriction } \\
\text { Presence of a police } \\
\text { force for restriction } \\
\text { (eg, confinement) } \\
\text { implementation } \\
\text { Ability to create places of } \\
\text { confinement for restricted } \\
\text { (eg, quarantined/isolated) } \\
\text { individuals }\end{array}$ \\
\hline
\end{tabular}

*These indicators depend on the intrinsic characteristics of the disease in question and need to be modified based on disease knowledge to be made dichotomous.

†This analysis incorporates the trade-off between total economic loss versus economic catastrophe averted in the form of saved lives. Such analyses routinely involve calculations over the value of statistical life or quality-adjusted life-years estimates. $^{30}$

$\mathrm{PHI}$, public health intervention.

of restrictions matches the trajectory of an outbreak. Reciprocity between the members of a community can have an impact on the equitable distribution of the burden of restriction. Commitment to accountability on the part of decision-makers can engender transparency and mechanisms of checking relevance (eg, conducting public polls on the acceptability of intervention), and can make decision-makers be aware of the problems to initiate a cascade of accountable remedies. Considerations made towards cost and feasibility of implementing a restriction can determine the utility efficiency and viceversa, while both these principles are conditional to the judgement of necessity. The interdependencies of the principles have a pragmatic value for the policymakers. It 
is conceivable that upholding or acting towards satisfying all the principles is improbable under the expectation of an urgent response in uncertain circumstances. For instance, limited and uncertain evidence for the magnitude of harm at the onset of an outbreak can make the measurement of harm challenging and thereby impede the judgement over necessity and justifiability. Additionally, the limited and uncertain epidemiological evidence can complicate defending whether or not a restriction is proportional. Hence, at the onset, against the contrast of inability to justify harm or determine the proportionality of the proposed intervention, the 'ethical focus' of policymakers should be on complementary principles such as transparency of communication, establishing accountability and conveying the need for reciprocity. Ensuring the basis for least restrictive means and equity becomes important too. As the biomedical, epidemiological and other implementation evidence emerge, policymakers can expand the focus to defending past actions and clarifying future decisions calibrating them according to harm, justifiability and proportionality principles.

\section{INDICATORS IN THE FRAMEWORK AND CONSIDERATIONS FOR APPLICATION}

Based on the principles that have been unified in the framework (table 1) and the notions represented by them, we first derived actionable considerations or answerable questions. Next, the considerations were mapped onto measurable indicators useful for initiating implementation, monitoring and evaluating restrictions. The importance of principles and the choice of indicators are contingent on the context. The relevance of the policy indicators to a country or local region is determined by, among other factors, the sociocultural acceptability of the corresponding ethical principle. For instance, the demand for the level of transparency along with what counts as transparent communication varies across societies. Hence, although transparency is desired across societies, the indicators for its suitable measurement might at times differ. Most of these indicators are based on easy-to-collect data that are available to the decisionmakers. Some specific analytical indicators might require the expertise of the technical (eg, economic) advisors. However, such aid is often available to high-level policymakers and health planners and can also be provided from global collaborations in the absence of local experts.

The current presentation of the framework consolidates the previous discussions around the ethics of movement restrictions as public health interventions (PHIs) into 11 unique principles. The ethical principles are mapped onto 34 policy indicators. For simplicity, 31 out of the 34 indicators (table 1 ) have been constructed to have dichotomous (yes or present/no or absent) responses of which 3 indicators (analysis of trade-off, matching stringency of measures with the growth of cases and deaths, and sufficient time intervals given for every restrictive step to show its desired effect) are specific to the infectious disease epidemic or pandemic. For instance, in the case of COVID-19, the least restrictive measure was recommended at least a week before the first case. ${ }^{24}$ However, this recommendation could vary for other pandemics. With evolving knowledge, the proposed framework could incorporate thresholds to dichotomise these indicators. The remaining three indicators (number of steps between the least and most restrictive measures, cost and population coverage of relief measures, and frequency of press conferences) have numerical responses with no normative thresholds. However, higher values for each of these indicators would depict greater adherence to the corresponding ethical principles. For instance, a greater number of steps between the least and most restrictive measures indicates that there was a gradual increase in the restrictions, which corresponds to greater adherence to the 'least restrictive means' principle. We do not suggest a fixed scoring system/rules for using the framework. The framework can be applied flexibly with suitable scoring at the discretion of the stakeholders. Generally, anyone with adequate knowledge and the necessary data can use the framework to critique the ethics of movement restrictions. More specifically, it is meant to be a systematic guide for policymakers (eg, local and national pandemic task force members) to ensure ethically sound movement-restricting policies. Before implementation of the movement restrictions, it can be used by the health planners/policymakers/task force for systematically considering the ethics of the movement restrictions. After implementation, it can be used for monitoring whether the ethical aspects of the restrictions are being upheld. It can also be used by independent researchers and policy analysts to assess or critique the ethical soundness of movement restrictions.

Here, we apply the framework to India's initial national lockdown during the COVID-19 pandemic. In our scoring, we consider that the ethical principles were satisfactorily adhered to if all the dichotomous indicators have an affirmative response (ie, yes) and partially adhered to if more than half the indicators corresponding to the principle had an affirmative response. We did not include the indicators that could not be made dichotomous in this scoring (table 2).

\section{APPLICATION OF THE FRAMEWORK TO THE NATIONAL-LEVEL INDIAN LOCKDOWN}

On 18 January 2020, much before the first COVID-19 case in India, India began airport screening of travellers from China. ${ }^{25}$ On 11 March, the Disaster Management Act was invoked, all visas were suspended and compulsory quarantine was initiated for all international travellers. ${ }^{25}{ }^{26} \mathrm{~A}$ voluntary curfew was proposed by the prime minister on 22 March and widely popularised by the media. ${ }^{27}$ India initiated the largest lockdown (here referred to as lockdown 1.0) in the world on $25 \mathrm{March}$ 2020 for 21 days, containing about 1.3 billion people (see online supplemental file 1). Subsequently, it was 
Table 2 Assessment of Indian national lockdown (1.0 and 2.0) from 24 March to 3 May 2020 for the performance with regard to policy indicators

\begin{tabular}{|c|c|c|c|}
\hline Ethical principle & $\begin{array}{l}\text { Policy monitoring and evaluation indicators for } \\
\text { response measures }\end{array}$ & $\begin{array}{l}\text { Performance of } \\
\text { indicator }\end{array}$ & $\begin{array}{l}\text { Did response measures } \\
\text { adhere to the principle? }\end{array}$ \\
\hline \multirow[t]{2}{*}{$\begin{array}{l}\text { Harm and } \\
\text { necessity }\end{array}$} & $\begin{array}{l}\text { Presence of scientific evidence indicating harm (eg, } \\
\text { human to human transmission, mortality) }\end{array}$ & $\checkmark$ & Yes \\
\hline & $\begin{array}{l}\text { Decided metric for harm measurement (eg, death } \\
\text { count, case count) }\end{array}$ & $\checkmark$ & \\
\hline \multirow[t]{3}{*}{ Justifiability } & $\begin{array}{l}\text { Presence of prior peer-reviewed scientific publications } \\
\text { on the effectiveness of restrictions }\end{array}$ & $\checkmark$ & Yes \\
\hline & - Successful historical precedent (any instance before) & $\checkmark$ & \\
\hline & $\begin{array}{l}\text { Presence of a dedicated response team for review of } \\
\text { literature, adequate data collection, impact evaluation } \\
\text { and situational monitoring to continuously determine } \\
\text { the effectiveness of the restrictions }\end{array}$ & $\checkmark$ & \\
\hline Proportionality & $\begin{array}{l}\text { Matching stringency of restrictions with the growth of } \\
\text { cases and deaths in the epidemic } \\
\text { In case of COVID-19: most restrictive measure (na- } \\
\text { tional lockdown) at least } 2 \text { weeks before 100th case } \\
\text { and least restrictive measure (travel bans) at least } \\
1 \text { week before first case }\end{array}$ & $x$ & No \\
\hline \multirow[t]{2}{*}{$\begin{array}{l}\text { Least restrictive } \\
\text { means }\end{array}$} & $\begin{array}{l}\text { The number of steps between the least (travel bans) } \\
\text { and the most restrictive (national lockdown) measures }\end{array}$ & 7 & Yes \\
\hline & $\begin{array}{l}\text { Whether sufficient time intervals are given for every } \\
\text { restrictive step to show the maximum effect }\end{array}$ & $\sqrt{ }^{*}$ & \\
\hline Utility efficiency & $\begin{array}{l}\text { Does the analysis of trade-off (eg, cost-benefit } \\
\text { analysis) between loss of livelihood and other losses } \\
\text { against deaths averted and cases averted show net } \\
\text { positive benefit? }\end{array}$ & $x$ & No \\
\hline \multirow[t]{8}{*}{ Reciprocity } & Cost and population coverage & $\begin{array}{l}\text { INR } 21.7 \text { trillion } \\
\text { (US } \$ 294 \text { billion) } \\
\text { covering } 420 \text { million } \\
\text { people }\end{array}$ & Partially \\
\hline & - Tax and loan payment concessions & $\checkmark$ & \\
\hline & $\begin{array}{l}\text { Postponing non-essential routine activities (eg, } \\
\text { examinations, sports events, etc) }\end{array}$ & $\checkmark$ & \\
\hline & - Anti-discriminatory mass media practices & $\checkmark$ & \\
\hline & $\begin{array}{l}\text { Guidelines in place for responsible news media } \\
\text { reporting to avoid discrimination and reduce stigma }\end{array}$ & $\times$ & \\
\hline & $\begin{array}{l}\text { Presence of helplines to deal with mental health issues } \\
\text { that may arise }\end{array}$ & $\checkmark$ & \\
\hline & $\begin{array}{l}\text { Surveys for awareness among people about avoiding } \\
\text { discrimination }\end{array}$ & $x$ & \\
\hline & $\begin{array}{l}\text { Presence of grassroots ventures that help the } \\
\text { impoverished groups }\end{array}$ & $\checkmark$ & \\
\hline \multirow[t]{4}{*}{ Transparency } & Presence of press conferences in local languages & $\checkmark$ & Yes \\
\hline & Frequency of COVID- 19 press conferences & $\begin{array}{l}\text { On average } 1 \text { in } 40 \\
\text { days }\end{array}$ & \\
\hline & $\begin{array}{l}\text { Presence of outreach methods and materials that are } \\
\text { easy to understand, in local languages, and widely } \\
\text { distributed }\end{array}$ & $\checkmark$ & \\
\hline & $\begin{array}{l}\text { Presence of a public record of justification for the } \\
\text { quarantine that is conveyed to lay people in local } \\
\text { languages }\end{array}$ & $\checkmark$ & \\
\hline
\end{tabular}




\begin{tabular}{|c|c|c|c|}
\hline Ethical principle & $\begin{array}{l}\text { Policy monitoring and evaluation indicators for } \\
\text { response measures }\end{array}$ & $\begin{array}{l}\text { Performance of } \\
\text { indicator }\end{array}$ & $\begin{array}{l}\text { Did response measures } \\
\text { adhere to the principle? }\end{array}$ \\
\hline \multirow[t]{2}{*}{ Relevance } & - Presence of public opinion polls & $\checkmark$ & Yes \\
\hline & $\begin{array}{l}\text { Presence of people's representatives in the decision- } \\
\text { making process of dedicated response teams }\end{array}$ & $\checkmark$ & \\
\hline \multirow[t]{3}{*}{ Equity } & $\begin{array}{l}\text { Presence of food and shelter security for the below } \\
\text { poverty line and low-earning unorganised labour } \\
\text { groups affected by the restrictions }\end{array}$ & $\checkmark$ & Partially \\
\hline & $\begin{array}{l}\text { Presence of domestic violence helplines for women } \\
\text { and children }\end{array}$ & $\checkmark$ & \\
\hline & $\begin{array}{l}\text { Availability of healthcare access for the chronically ill } \\
\text { and elderly groups }\end{array}$ & $\times$ & \\
\hline \multirow[t]{5}{*}{ Accountability } & - Presence of grievance redressal and feedback portals & $\checkmark$ & No \\
\hline & $\begin{array}{l}\text { Presence of public platforms to challenge the } \\
\text { restrictions by speaking to authority figures }\end{array}$ & $x$ & \\
\hline & Presence of laws that allow for a process of appeal & $\checkmark$ & \\
\hline & $\begin{array}{l}\text { Uninterrupted and autonomous working of the judicial } \\
\text { system for fast-tracking the restriction-related appeals }\end{array}$ & $\times$ & \\
\hline & $\begin{array}{l}\text { Mechanisms for demanding reparations in case of life } \\
\text { and livelihood losses due to restriction }\end{array}$ & $x$ & \\
\hline \multirow[t]{3}{*}{ Cost and feasibility } & $\begin{array}{l}\text { Presence of laws that allow the implementation of } \\
\text { restriction }\end{array}$ & $\checkmark$ & Yes \\
\hline & $\begin{array}{l}\text { Presence of a police force for restriction (eg, } \\
\text { confinement) implementation }\end{array}$ & $\checkmark$ & \\
\hline & $\begin{array}{l}\text { Ability to create places of confinement for restricted } \\
\text { (eg, quarantined/isolated) individuals }\end{array}$ & $\checkmark$ & \\
\hline
\end{tabular}

$\checkmark=$ yes or present; $X=$ no or absent.

${ }^{*}$ Sufficient time interval given for every restrictive step to show the maximum effect was derived from ${ }^{31}$ which calculated the time taken for travel restrictions, school/workplace/public place closures and lockdowns to show maximum effect. No recommendations were given for social distancing measures. Of the three restrictive measures, India followed the minimum time requirement for travel restrictions and lockdown but not for school/workplace/public place closures. Since more than half of the available minimum time standards were met, we considered this indicator to have 'yes' as the response.

INR, Indian rupee.

extended into lockdown 2.0 (15 April-3 May), lockdown 3.0 (4 May-17 May) and lockdown 4.0 (18 May-31 May), followed by phased reopening or unlock periods. ${ }^{28}$ For a while, some restrictions stood in place, with a push towards safely restarting the economy. However, in light of the disastrous second wave of COVID-19, lockdowns have re-emerged across various Indian states. ${ }^{29}$ Here, as an example, we apply the framework to lockdowns 1.0 and 2.0 that were imposed by the Central Government of India. We do not include lockdown phases 3.0 and 4.0 as the decision-making became more locally driven during these with individual state governments and authorities playing a greater role, thereby making assessment challenging.

Our findings for Indian lockdown phases 1.0 and 2.0 are summarised in table 2 and extensively described with references to evidence in the online supplemental file 2. We find that most indicators were readily available in the preprint and academic literature and policy documents. The indicators: considering sufficient time intervals for every restrictive step to show maximum effect and the frequency of press conferences were based on simple calculations of extracted data. Of the 31 dichotomous policy indicators, 23 had an affirmative response. Principles of harm, justifiability, transparency, least restrictive means, and cost and feasibility were satisfactorily adhered to, while those of reciprocity and equity were partially adhered to. Proportionality, utility efficiency and accountability were not adhered to according to our scoring system (table 2). It is critical to note that the adherence to ethical principles is contingent on the scoring criteria used here and can be determined differently by other evaluators depending on the context.

\section{LIMITATIONS OF THE FRAMEWORK AND ITS CURRENT APPLICATION}

Limitations of the current analysis can be grouped into those relating to the framework itself and those in its current application. With regard to the framework, the current study lacks a validity assessment of the framework. Here, our aim is to introduce the framework and present 
an example of its application to India's lockdown. A formal assessment of content and criterion validity needs to be conducted. Even so, to ensure content validity, we mapped several policy indicators to a given ethical principle with the aim to cover multiple facets covered across literature under that principle. Given that there is no 'gold standard' for comparison, assessment of criterion validity might be a challenge.

The presence of possible ceiling and flooring effects is an important limitation in the current application of the framework. These effects arise from the use of dichotomised indicators. Categorical indicators, such as dichotomised indicators, are used as they facilitate easy application, interpretation and comparison. In the future, discrete responses or ordinal responses with levels could replace the dichotomisation to avoid potential flooring and ceiling. Further, we used the arbitrary threshold of 'at least half of the indicators being affirmative' to decide whether the ethical principle was adhered to. In our analysis, although 23 out of 31 dichotomous indicators had 'yes' as an answer, the relative proportion of the indicators within the principles leads to the conclusion that several ethical principles were not completely or partially adhered to. Changing this threshold can lead to qualitatively different conclusions. Here, our attempt was to demonstrate a simple application of the framework hence we did not test the conclusions across different thresholds. Future studies could choose different thresholds deemed suitable for the scenario at hand or better yet, present a range of conclusions sensitive to the different thresholds. While it might increase analytical complexity, studies could also assign differential weights to the indicators or use different methods of aggregation better suited for the assessment at hand. Finally, we applied the framework to the national-level lockdown in India, which simplifies the subnational socioepidemiological heterogeneities and does not consider the variations in the state or further local-level response measures. However, with more granular data, investigators and policymakers at any level in the administrative hierarchy can apply the framework to the administrative geographical unit (eg, state or district or municipality containment zone) of their interest. Such an application will need to use the policy indicators at the multiple decision-making levels, that is, state-level analyses would consider both national and state policies on movement restrictions.

\section{CONCLUSION}

We describe a framework bridging pragmatic policy indicators to the ethical principles that the movement restrictions imposed as PHI against pandemics should adhere to. The rigorous scope, easy interpretability, and flexible application of the framework make it suitable for use by health policymakers and planners for initiating a movement restriction, monitoring the developments, and post-implementation evaluation. As an example, we also showcased the framework's application for evaluation of the nationwide lockdown in India to demonstrate its ethical soundness. We believe that our framework that systematically bridges ethics to policies can come in handy in the evolving COVID-19 pandemic and possible future outbreaks.

Acknowledgements We thank Dr Sweta Dubey for insightful discussions while developing the framework and everyone at ASAR for their support.

Contributors Study concept and design-SZ. Acquisition, analysis or interpretation of data-PM and SD. Drafting of the manuscript-SZ. Drafting of the supplement-PM. Literature review-PM and SD. Critical revision of the manuscript for important intellectual content-all authors. Administrative, technical or material support-SZ and SD. Study supervision-SZ.

Funding The authors have not declared a specific grant for this research from any funding agency in the public, commercial or not-for-profit sectors.

Competing interests None declared.

Patient consent for publication Not required.

Provenance and peer review Not commissioned; externally peer reviewed.

Data availability statement All data relevant to the study are included in the article or uploaded as supplementary information.

Supplemental material This content has been supplied by the author(s). It has not been vetted by BMJ Publishing Group Limited (BMJ) and may not have been peer-reviewed. Any opinions or recommendations discussed are solely those of the author(s) and are not endorsed by BMJ. BMJ disclaims all liability and responsibility arising from any reliance placed on the content. Where the content includes any translated material, BMJ does not warrant the accuracy and reliability of the translations (including but not limited to local regulations, clinical guidelines, terminology, drug names and drug dosages), and is not responsible for any error and/or omissions arising from translation and adaptation or otherwise.

Open access This is an open access article distributed in accordance with the Creative Commons Attribution Non Commercial (CC BY-NC 4.0) license, which permits others to distribute, remix, adapt, build upon this work non-commercially, and license their derivative works on different terms, provided the original work is properly cited, appropriate credit is given, any changes made indicated, and the use is non-commercial. See: http://creativecommons.org/licenses/by-nc/4.0/.

\section{ORCID iDs}

Siddhesh Zadey http://orcid.org/0000-0003-1176-1529

Surabhi Dharmadhikari http://orcid.org/0000-0001-9496-9522

Pradeeksha Mukuntharaj http://orcid.org/0000-0002-6487-0692

\section{REFERENCES}

1 Dong E, Du H, Gardner L. An interactive web-based dashboard to track COVID-19 in real time. Lancet Infect Dis 2020;20:533-4.

2 bsg. Oxford COVID-19 government response Tracker, 2020. Available: https://www.bsg.ox.ac.uk/research/research-projects/ coronavirus-government-response-tracker

3 Islam N, Sharp SJ, Chowell G, et al. Physical distancing interventions and incidence of coronavirus disease 2019: natural experiment in 149 countries. BMJ 2020;370:m2743.

4 Reuter's Staff. Wuhan lockdown 'unprecedented', shows commitment to contain virus: WHO representative in China, 2020. Available: https://fr.reuters.com/article/us-china-health-who/wuhanlockdown-unprecedented-shows-commitment-to-contain-viruswho-representative-in-china-idINKBN1ZM1G9

5 Sandford A. Coronavirus: half of humanity now on lockdown as 90 countries call for confinement., 2020. Available: https://www. euronews.com/2020/04/02/coronavirus-in-europe-spain-s-deathtoll-hits-10-000-after-record-950-new-deaths-in-24-hou

6 Alfano V, Ercolano S. The efficacy of Lockdown against COVID-19: a Cross-Country panel analysis. Appl Health Econ Health Policy 2020;18:509-17.

7 Ghosal S, Bhattacharyya R, Majumder M. Impact of complete lockdown on total infection and death rates: a hierarchical cluster analysis. Diabetes Metab Syndr 2020;14:707-11.

8 International Labour Organization. ILO monitor: COVID-19 and the world of work. 6th ed. International Labour Organization, 2020. https://www.ilo.org/wcmsp5/groups/public/@dgreports/@dcomm/ documents/briefingnote/wcms_755910.pdf 
9 United Nations Children's Fund. Covid-19: are children able to continue learning during school closures? a global analysis of the potential reach of remote learning policies using data from 100 countries. New York: UNICEF, 2020. https://data.unicef.org/ resources/remote-learning-reachability-factsheet/

10 The World Bank. Projected poverty impacts of COVID-19 (coronavirus), 2020. Available: https://www.worldbank.org/en/topic/ poverty/brief/projected-poverty-impacts-of-COVID-19

11 Thejes GN. COVID non-virus deaths in India, 2020. Available: https:// thejeshgn.com/projects/covid19-india/non-virus-deaths/

12 May T. Lockdown-type measures look effective against covid-19. BMJ 2020;370:m2809.

13 UN News, Health. COVID-19: Lockdown across India, in line with who guidance. un news, 2020. Available: https://news.un.org/en/ story/2020/03/1060132 [Accessed 14 Apr 2021].

14 Laxminarayan R. What India needs to fight the virus. the new York times, 2020. Available: https://www.nytimes.com/2020/03/27/ opinion/india-coronavirus-lockdown.html [Accessed 14 Apr 2021].

15 Kumar S, Choudhury S. Migrant workers and human rights: A critica study on India's COVID-19 lockdown policy. Soc Sci Humanit Open 2021;3:100130.

16 India under COVID-19 lockdown. Lancet 2020;395:1315.

171.3 billion people. A 21-day lockdown. Can India curb the coronavirus?2020. Available: https://www.sciencemag.org/news/ 2020/03/13-billion-people-21-day-lockdown-can-india-curbcoronavirus[Accessed 13 Apr 2021].

18 Barbera J, Macintyre A, Gostin L, et al. Large-Scale quarantine following biological terrorism in the United States: scientific examination, logistic and legal limits, and possible consequences. JAMA 2001;286:2711.

19 Upshur REG. Principles for the Justification of public health intervention. Can J Public Health 2002;93:101-3.

20 Upshur REG. The ethics of quarantine. AMA Journal of Ethics 2003;5.

21 World Health Organization. Ethical considerations in developing a public health response to pandemic influenza, 2007. Available: https://www.who.int/csr/resources/publications/WHO_CDS_EPR GIP 2007 2c.pdf

22 Presidential Commission for the study of bioethical issues. ethics and Ebola public health planning and response, 2015. Available: https://bioethicsarchive.georgetown.edu/pcsbi/sites/default/files/ Ethics-and-Ebola_PCSBI_508.pdf

23 World Health Organization. Guidance for managing ethical issues in infectious disease outbreaks, 2016. Available: http://apps.who.int/ iris/bitstream/10665/250580/1/9789241549837-eng.pdf

24 Koh WC, Naing L, Wong J. Estimating the impact of physical distancing measures in containing COVID-19: an empirical analysis. Int J Infect Dis 2020;100:42-9.

25 PIB, New Delhi. India's response to COVID outbreak. Press Information Bureau. Available: https://pib.gov.in/PressReleasePage. aspx?PRID=1608727 [Accessed 25 Jan 2021].

26 Yadavar S, Mandhani A. Modi govt is using two laws to tackle coronavirus spread. but one of them needs changes, the print, 2020 Available: https://theprint.in/theprint-essential/modi-govt-is-usingtwo-laws-to-tackle-coronavirus-spread-but-one-of-them-needschanges/386052/ [Accessed 25 Jan 2021].

27 Chandna H, Basu M. Modi announces 'Janata Curfew' on 22 March, urges for resolve, restraint to fight coronavirus. The Print, 2020. Available: https://theprint.in/india/modi-announces-janata-curfewon-22-march-urges-for-resolve-restraint-to-fight-coronavirus/ 384138/ [Accessed 25 Jan 2021].

28 The wire. COVID-19 India Timeline. Available: https://thewire.in/ covid-19-india-timeline [Accessed 25 Jan 2021].

29 Several states impose lockdown or strict curbs as Covid catastrophe continues. times of India, 2021. Available: https://timesofindia. indiatimes.com/india/several-states-impose-lockdown-or-strictcurbs-as-covid-catastrophe-continues/articleshow/82502252.cms [Accessed 10 May 2021].

30 Conover C. How economists calculate the costs and benefits of COVID-19 Lockdowns. How economists calculate the costs and benefits of COVID-19 Lockdowns, 2020. Available: https://www. forbes.com/sites/theapothecary/2020/03/27/how-economistscalculate-the-costs-and-benefits-of-covid-19-lockdowns/\# 1e25ed656f63

31 Li Y, Campbell H, Kulkarni D, et al. The temporal association of introducing and lifting non-pharmaceutical interventions with the time-varying reproduction number $(\mathrm{R})$ of SARS-CoV-2 a modelling study across 131 countries. Lancet Infect Dis 2021;21:193-202. 